\title{
ERRATUM \\ Erratum to: Species Occupancy Modeling for Detection Data Collected Along a Transect
}

\author{
Gurutzeta Guillera-Arroita, Byron J.T. Morgan, \\ Martin S. RIDOUT, and Matthew LINKIE
}

Erratum to: J. Agric. Biol. Environ. Stat.

DOI 10.1007/s13253-010-0053-3

Expression (2.8) is missing a factor $L$ in the denominator. It should read

$$
\operatorname{cov}(\hat{\psi}, \hat{\lambda})=\frac{-\lambda}{S}\left\{\frac{1-\lambda^{*}}{\lambda^{*}-\left(1-\lambda^{*}\right) \lambda L}\right\} .
$$

This does not affect any of the results presented in the paper.

[Published Online June 2011.]

\begin{abstract}
The online version of the original article can be found under doi:10.1007/s13253-010-0053-3.
Gurutzeta Guillera-Arroita $(\varangle)$ is a Ph.D. Student (E-mail: gg63@kent.ac.uk), Byron J.T. Morgan is Professor of Applied Statistics (E-mail: b.j.t.morgan@kent.ac.uk) and Martin S. Ridout is Professor of Applied Statistics (E-mail: m.s.ridout@kent.ac.uk), School of Mathematics, Statistics and Actuarial Science, University of Kent, Canterbury, CT2 7NZ, UK and are part of the National Centre for Statistical Ecology. Matthew Linkie (E-mail: matthew.linkie@ffi.or.id) is Programme Manager, Fauna \& Flora International (FFI) in Aceh, Jln Tgk. Chik Dipasi No. 50, Desa Limpok, Darussalam, Aceh Besar, Nanggroe Aceh Darussalam 23373, Indonesia and Honorary Research Fellow at the Durrell Institute of Conservation and Ecology, University of Kent, Canterbury, CT2 7NR, UK.
\end{abstract}

